Journal of Teacher Education for Sustainability, vol. 15, no. 2, pp. 42-51, 2013

\title{
MANAGING COGNITIVE DISSONANCE: EXPERIENCE FROM AN ENVIRONMENTAL EDUCATION TEACHERS’ TRAINING COURSE IN THE CZECH REPUBLIC
}

\author{
Jan Cincera \\ Technical University of Liberec, the Czech Republic
}

\begin{abstract}
This paper presents a qualitative evaluation of seven in-service environmental education teacher training courses conducted in the Czech Republic in 2009-2011. The evaluation applied a grounded theory approach. 14 focus groups, 13 interviews and two postprogramme questionnaires were used. The evaluation describes a process of managing cognitive dissonance between the participants' concepts of effective teaching and environmental education and concepts presented by the courses. The paper discusses the strategies applied by the course managers for facilitating a conflict and defensive mechanisms used by the participants. The paper also discusses the implication of this experience for future courses.
\end{abstract}

Key words: in-service teachers' training, cognitive dissonance, environmental education, qualitative research, evaluation

\section{Introduction}

Effective environmental education (EE) calls for effective educators. However, what competencies should an effective EE educator possess? And what teaching strategies should be applied for work with a group of in-service environmental educators?

Although authors have investigated environmental literacy of pre-service or inservice teachers (Boyes, Chambers, \& Stanisstreet, 1995; Corney, 2000; Hsu \& Roth, 1999; Pe'er, Goldman, \& Yavetz, 2007; Matejcek \& Bartos, 2012), much less research has been carried out on teachers' competence in EE. Ham and Sewing (1988) found various barriers to EE caused by a narrow focus of teachers on cognitive aspects of EE and the lack of commitment to teach EE. Stevenson (2007) mentioned contradictions between school practice and EE. According to him, EE calls for an interdisciplinary approach, real practical problems and cooperation, but school curricula are usually discipline-based, solve abstract problems and support individualism. It is reasonable to suppose that environmental educators need special competencies in addition to their common in-service training.

There is no universal definition of what competencies environmental educators should have. The North American Association for Environmental Education (NAAEE, 2010) defines a comprehensive set of competencies for environmental educators. The 
guidelines include the six main themes required for teachers: educators must be competent in skills and understanding enlisted in guidelines for EE at elementary and secondary schools; they must understand goals, theory, practice and history of EE; they must understand and accept the responsibility associated with EE; they must be able to design and implement effective instruction, motivate pupils in open inquiry and investigation; they must possess competence for assessment and evaluation.

In the Czech Republic, however, such guidelines do not exist. Regardless of the effort of Horka (2003) and others, there is still a lack of consensus about what competencies environmental educators should have. As a result, there are many different preservice and in-service training programmes that focus on different sets of competencies and apply different instructional strategies.

Moreover, effectiveness of such programmes is rarely evaluated, making it difficult to determine what strategies work and what do not. Winther (2005) questioned the effectiveness of short-time training courses. According to him, short-time courses may have a negative effect on teachers' self-efficacy and motivation. Moseley, Reinke and Bookout (2002) found no immediate effect of a 3-day outdoor training course on teachers' self-efficacy and a negative effect in the longer time-period. Winther, Volk and Schrock (2002) noticed problems with implementation of new methods in the school context. Corney and Fortner (1999) reported success of extensive teacher training in science on students' process skills and environmental knowledge. Pace (2010) found that a key factor that influenced the effects of pre-service teachers programmes on EE and education for sustainable development was its experiential methodology rather than its content.

In the Czech Republic, a coordinator of EE should work at every school. According to the guidelines launched by the Czech Ministry of Education (MSMT, 2008), coordinators are supposed to participate in a 250-hour training course. Although the content of such courses is roughly provided, the guidelines miss clear objectives that would allow them to be evaluated. As a result, participant satisfaction has become the main indicator of success. However, such an indicator may be highly deceptive. The qualitative evaluation of selected courses for EE coordinators showed that, although graduates were highly satisfied with their courses, they had a poor understanding of both the goals and the means of EE (Cincera, Gilar, \& Sokolovicova, 2010).

The aim of the project conducted in cooperation of seven Czech EE centres, the Technical University of Liberec and the Association of Environmental Education Centres Pavucina was to redefine goals, objectives and content of EE training courses. As a part of the project, supported by the European Social Funds and the Czech government, seven courses in different regions of the Czech Republic in 2009-2011 were conducted. This paper presents the qualitative part of the project's evaluation.

\section{Programme}

All of the courses followed the same guidelines. The participants developed their competencies for planning, coordinating and applying EE in their practice. To achieve this, they learned to analyse educational and organisational needs in their respective schools in order to set specific and measurable goals and objectives and to select appropriate means to achieve them, to evaluate their effectiveness, to design a new project proposal, to present their projects to an audience, etc. The programme's theory was underpinned by two essential assumptions that we could call a concept of EE and a concept of effective teaching. 
The concept of EE was based on the acceptance of responsible environmental behaviour as the ultimate aim of EE (Hungerford \& Volk, 1990). The participants were supposed to understand strategies needed to develop key variables associated with responsible environmental behaviour, like environmental sensitivity, issue analyses, action competencies etc. (Hungerford, Peyton, \& Wilke, 1980; Hungerford \& Volk, 1990).

The concept of effective (or good) teaching has been discussed in many publications and usually subsumes more aspects, like subject knowledge, teaching skills, etc. (Parpala, Lindblom-Yläne, \& Rytkönen, 2011). In the programme, it simply expressed the importance of planning curricula 'from goals to means' and not from the content or familiar activities. Participants had to prepare a sound plan of EE, applying knowledge of the programme theory, learning models or evaluation strategies (Braus \& Wood, 1993; Hungerford, 2005; NAAEE, 2004).

Although the courses followed the same guidelines, differences in implementation appeared. The course managers had to adjust the course activities to the needs of their groups. In some cases, they also tended to highlight different areas of the course content.

\section{Evaluation methodology}

This paper focuses on two evaluation questions: How was the course interpreted by its students? and What factors influenced this interpretation?

To answer them, the following set of instruments for data collection was used:

- focus groups with 8-10 students in the first part of the courses $(7$ groups, $\mathrm{n}=52$ );

- focus groups with the same participants in the last part of the courses ( 7 groups, $\mathrm{n}=52)$;

- post-course questionnaire with open-ended questions for all the participants on the last day of their courses $(n=139)$;

- post-course questionnaire with open-ended questions for all the participants six month after finishing their courses $(n=144)$;

- interviews with the course managers 3-5 months after the courses $(n=13)$.

The data was collected by the four evaluators and (with the exception of the interviews) in the absence of the programme managers. All of the interviews were recorded and transcribed. The analysis followed principles of the grounded theory (Glaser, 1978, 1998; Corbin \& Strauss, 2008). In the first step, the evaluator selected the data segments for the following coding procedure (Saldana, 2009). In the first level of coding, all of the segments were coded in an open coding process that generated substantive concepts and memos. In the second level, the coding process and more general categories were developed. In the last part, the categories were integrated around a newly emerging core category - managing cognitive dissonance. The new theory seemed to be powerful enough to explain social processes that occurred in the group. To increase its reliability, the theory was further discussed with the course managers. When all of them supported its relevance, the analysis was finished.

The number of respondents varied among different sets of data. Table 1 provides information about the total number of participants. All of the participants were asked to fill in post-course questionnaires. For the focus groups, the participants were purposefully selected to obtain heterogeneous groups. Although a purposeful sampling is the recommended strategy for qualitative evaluation (Patton, 2002), the groups' heteroge- 
neity contradicts the recommendation for focus groups. According to Morgan (1997), homogenous groups allow for more free-flowing conservation and are more appropriate for focus groups. However, even if differences in opinions in the groups might appear, the similarities based on their common profession and interest established a common ground for open discussions.

Table 1. Participants of the courses

\begin{tabular}{lclcll}
\hline Number of participants & 176 & Age (mean) & 41 & Sample for focus groups & 52 \\
\hline Women & 149 & Standard deviation & 9 & Men in focus groups & 14 \\
\hline Men & 27 & $\begin{array}{l}\text { Years of practice } \\
\text { (mean) }\end{array}$ & 14 & Women in focus groups & 38 \\
\hline
\end{tabular}

The interviews were recorded with 13 of the 14 course managers from all the seven courses. Since differences in opinions among the managers were supposed, the interviews were conducted individually. In the analysis, full anonymity of respondents was granted.

\section{Results}

\section{Initial clash}

Although motivation for participating in the course and participants' experience in EE differed, some of the participants had practiced EE for a long time. Because of this, they supposed the course would be a 'stock-market', an opportunity for exchanging ideas about their experience and practice. They expected to learn new activities, useful contacts and finally receive a certificate that would increase their status at schools. They often had a fixed set of concepts of EE and effective teaching; they believed they were good environmental educators and did not expect to change their mind.

According to the most common concept of EE, it was 'nature education'. The participants believed that, if pupils learned about nature, they would not damage it. They also believed that the goals of EE were clear and intuitive.

(EE) is not a science; it is a matter of opinion ... what is important for me is if children will not break branches. (a male participant)

The participants were not usually used to planning their lessons. If they taught EE, they prepared lessons intuitively, based on topics they believed were associated with EE or on activities they knew and liked. As a result, the participants' concepts of EE and effective teaching clashed with concepts presented by the courses. During this clash, strong negative emotions appeared.

The first homework was like a shower, and we all were feeling stupid and did not understand a word. What language do they speak with us? (a female participant)

\section{Managing cognitive dissonance}

In the evaluation, managing cognitive dissonance was identified as a core category. It defines the ways the participants dealt with the clash between their initial concepts and 
the concepts presented by the courses. The participants had to choose between two options. They could reject new and retain their original concepts, or they could reject original and accept new concepts. Such a decision was facilitated by a strategy applied by the course managers and self-vindicated by a defensive strategy applied by the participants.

Being confronted with negative emotions of their participants, the course managers chose one of possible strategies for managing the conflict. In some of the courses, the coordinators decided to calm the negative emotions by diminishing a space for activities connected with the new concepts (like goal setting) and focusing on activities expected by the participants (like educational activities). As a result, the groups' satisfaction grew. The participants also reflected increased motivation. On the other hand, most of them did not change their initial concepts.

In other courses the coordinators were not successful in managing the conflict. For a certain part of each of the courses, the participants were disagreed with their coordinators. They reflected their coordinators as 'unpleasant' or 'not sympathetic'. Although the level of satisfaction was low in these groups, in the course of time, the majority of these participants were able to cope with it and at least partially open themselves for the new concepts.

The coordinators were successful in facilitating the conflict. They did not try to avoid it, but managed it without strong negative emotions. The coordinators were able to express a sympathetic attitude towards participants, but they did not give up on teaching the concepts presented in the courses. It should be noted that the majority of the participants opened themselves towards the new concepts.

Three other factors of successful facilitating appeared: modelling, linking a theory with the practice and management of break-points. When the course managers were congruent with the concepts of the courses, they were also able to apply them in their lessons. This strategy promoted the participants' thinking about the concepts and modelled a way EE might be conducted in the school environment. On the other hand, the coordinators who had objections against some part of the concepts usually did not apply them. The new concepts were introduced in separate lessons as theoretical units. It caused that participants who did not want to replace their original concepts labelled the new concepts as 'theory', separated from their living 'practice'.

To avoid such a classification, it was necessary to link the new concepts with what the participants knew as 'practice'. There were three dimensions of linking: in a lesson, between a lesson and the participants' practice and among activities in the course. When teachers learned to formulate measurable objectives, they needed to practice them in the lesson. They needed to apply themto homework connected with their school practice. Finally, the new knowledge needed to be repeated, reinforced and modelled during subsequent course activities.

Unique opportunities for changing the participants' concept in a single moment appeared during some of the courses. When it happened, the way the managers were able to manage these break-points couldhave influenced the rest of the courses. In one of the courses, the participants experienced a field trip with simple nature observation activities. During this, a manager asked the participants if they thought they were doing EE. This question opened a heated discussion. The participants' concept of EE as nature education was confronted and deconstructed.

A big clash and even a breakpoint for some occurred there, they said, OK, it might be different than I had thought... It was good feedback, in fact, the 
fact that they kept going back to it, discussed the walk, wanted to talk about it in the evening. And, there, I think the crash was ... that what we did was what they had been usually doing. They had been going out with children and supposed it was environmental education. And so we discussed what we could do to change a trip to the countryside into environmental education. (a female course manager)

Being confronted with new concepts, facilitated by the course managers, the participants could vindicate their original position by applying various defensive mechanisms. Three of them were the most common: 'theory is for theoreticians', 'not in my school' and 'new labels for old things'.

In all of them, the participants evaluated the new concepts as useless. As 'practice' they classified learning content that did not contradict their initial concepts and expectations. Examples of activities, school presentations and educational materials could be easily implanted into participants' practice. Needs analysis, goal setting, learning models or evaluation strategies could not be easily implemented without changing participants' concepts of effective teaching and so were classified as 'theory'.

Other participants admitted some importance of theory. However, they stated reasons why it could not be applied to their schools. Usually, they complained about the lack of cooperation among teachers, lack of support from their head teachers and lack of time.

A coordinator of environmental education should be properly paid and ... should have fewer lessons to have time for the job. My experience is that our headmaster is absolutely unsupportive of this and my colleagues bugger it too. (a female participant)

Finally, for some of the participants, the new concepts were just new labels for old things. They believed that theory is just af complicated description of a common practice. Because of this, they believed that no changes in the way they teach are needed.

\section{Conceptual shift}

As a result, shallow or deep learning occurred. At the shallow level, the participants acquired knowledge, skills and attitudes that did not change their initial concepts. The participants learnt new activities, got new contacts, designed project proposals and increased their motivation. They also verified their initial concepts.

What I got from the course: contacts with super mates and their friendship, some knowledge about environmental education and especially confirmation that I am a man who does not like theory. (a male participant)

At the deep level, the participants reported deep changes in their practice. They reflected that the conceptual change helped them to re-create a school system of EE and reorganise their curricula.

Only now, I realise that theory is important and even interesting and only now I would need another course ... because what I have taken from this course is that what I had done (in environmental education) was by no means good ... (a female participant) 
Because these participants acquired competencies useful for any subjects, they increased their status at school.
Environmental education at our school is now systematic, not single shots here and there. More people have joined. I have learnt to engage people in a problem, better organise my work. (a female participant)

\section{Discussion}

The cognitive dissonance as an issue in in-service environmental educators' training is not new. Winther et al. (2002) reported a similar experience from courses of issue investigation and the action training model (Bardwell, Monroe, \& Tudor, 1994; Marcinkowski, 2004). The respondents admitted that the new curriculum differed from their practice and complained about its difficulty. They also reported their colleagues' incomprehension.

Being confronted with new concepts, students might refuse a change and assimilate new knowledge into existing concepts, or they can accommodate new concepts and reject the old ones (Kolb, 1984). The process of cognitive dissonance might be challenging. In the study, the experienced participants with long practice and high self-efficacy reacted highly emotionally to the new concepts.

According to Bandura (1977), self-efficacy is one of the key motivational drivers and behavioural precondition. It is defined as a belief that one can perform successfully using their skills adequately (Postareff, 2007). In the teaching context, it is important for teachers' motivation towards their job (Ignat \& Clipa, 2010; Moseley, Reinke, \&Bookout, 2002). Self-efficacy develops on the bases of successful experience, external evaluation and self-evaluation (Bandura, 1977; Ignat \& Clipa, 2010).

However, the lack of evaluation culture is a weakness of the Czech educational system. Teachers are not used to receiving feedback about their practice (Santiago, Gilmore, Nusche, \& Sammons, 2012). It may lead to a conclusion that teachers' selfefficacy was developed on the basis of inappropriate feedback. Teachers were aware that by infusing experiential activities into their curricula they would increase enjoyment of their pupils and believed that a higher effectiveness of their lessons would be the result. Teachers might believe that the implementation of experiential activities is enough to be an effective teacher. Because of this, their concept of effective teaching was focused on content and activities, not on goals and planning. After years of experience, these teachers were sure in what they did and what they wanted. Challenging this in the course meant challenging the way teachers had been interpreting themselves for years.

Rich and Hannafin (2009) argue that, in order to prevent teachers from discarding evidence contradicting with their beliefs, it is essential to provide experience in a way that does not threaten their self-concept. However, if teachers are supposed to accommodate new concepts, they must go through a painstaking process of challenging their self-efficacy. It opens a way not only towards an emotionally demanding conflict but also towards deep learning.

The emotionality of the process might be further explained by the theory of single and double-loop learning. According to Argyris (1976, 1995), we are often faced with a contradiction between espoused theory and theory-in-use. Reasons for such contradictions might be the lack of feedback, self-evaluation or the school context collectively maintaining old practice. When students are not aware of this, single-loop learning 
appears. Old practice is maintained, although enriched with new skills. Being made aware of the discrepancies between their espoused theory and the theory-in-use, students usually react emotionally and use various self-defensive mechanisms. They typically defend their standpoint and attribute their failure to external causes.

This is what happened in the study: the teachers defended their standpoint by criticising 'theoreticians' or by attributing their failure to the lack of cooperation, dysfunctional relationships, overwhelming paper-work or other problems in their schools. Only when these mechanisms are overcome, double-loop learning where students challenge their common practice and try to harmonise it with their espoused theory might start.

\section{Conclusion}

This paper described the process of managing cognitive dissonance as a crucial aspect of in-service teacher training course in the field of EE. In the light of this, cognitive dissonance should be accepted as a natural part of learning process in teacher training courses. Even if this process might temporally decrease the level of participants' satisfaction, course managers should avoid temptation to calm it down by replacing challenging concepts with more acceptable topics. To successfully facilitate cognitive dissonance, the managers should pay attention to congruency between what and how they teach in the course. Special attention should also be paid to linking new concepts with practical examples from school environment. Although this paper identified some effective and ineffective strategies for dealing with cognitive dissonance, a better understanding of the process is needed, as it opens an opportunity for further either qualitative or quantitative research.

\section{References:}

Argyris, C. (1976). Single-loop and double-loop models in research on decision making. Administrative Science Quarterly, 21(3), 363-375.

Argyris, C. (1995). Action science and organizational learning. Journal of Managerial Psychology, 10(6), 20-26.

Bandura, A. (1977). Self-efficacy: Toward a unifying theory of behavioral change. Psychological Review, 84(2), 191-215.

Bardwell, L. V., Monroe, M. C., \& Tudor, M.T. (1994). Environmental problem solving. Theory, practice and possibilities in environmental education. Troy: North American Association for Environmental Education.

Boyes, E., Chambers, W., \& Stanisstreet, M. (1995). Trainee primary teachers' ideas about the ozone layer. Environmental Education Research, 1(2), 133-145.

Braus, J. A., \& Wood, D. (1993). Environmental education in the schools. Creating a program that works! Washington: North American Association for Environmental Education.

Cincera, J., Gilar, P., \& Sokolovicova, J. (2010). Specializacni studium pro koordinatory environmentalni vychovy, vzdelavani a osvety: interpretace a efektivita z pohledu absolventu [A training course for in-service environmental education coordinators]. Envigogika, 5(1). Retrieved October 10, 2013, fromhttp:/www.envigogika.cuni.cz/ index.php/Envigogika/article/view/47 
Corbin, J., \& Stauss, A. (2008). Basics of qualitative research. Techniques and procedures for developing grounded theory. Thousand Oaks: Sage.

Corney, G. (2000). Student geography teachers' pre-conceptions about teaching environmental topics. Environmental Education Research, 6(4), 313-329.

Corney, J. R., \& Fortner, R. W. (1999) Does teacher education translate into student gains? Evaluation of an Earth systems education program conducted in Great Lakes area middle schools. Washington: North American Association for Environmental Education conference.

Glaser, B. G. (1978). Theoretical sensitivity: Advances in the methodology of grounded theory. San Francisco: Sociology Press.

Glaser, B. G. (1998). Doing grounded theory: Issues and discussions. Mill Valley: Sociology Press.

Ham, S. H., \& Sewing, D. R. (1988). Barriers to environmental education. The Journal of Environmental Education, 19(2), 17-24.

Horka, H. (2003). Standard pregradualni ekologicke/environmentalni pripravy ucitelu [Standard for ecological/environmental pre-service teacher training]. In E. Liskova (Ed.), Minimalni vseobecny zaklad znalosti a dovednosti studentu ucitelstvi o zivotnim prostredi, udrzitelnem rozvoji a environmentalni vychove [Basic general standards of knowledge and skills about the environment, sustainable development and environmental education for pre-service teachers] (pp. 4-6). Praha: Univerzita Karlova.

Hungerford, H. R. (2005). The general teaching model (GTM). In H. R. Hungerford, W. J. Bluhm, T. L. Volk \& J. M. Ramsey (Eds.), Essential readings in environmental education (pp. 423-433). Champaign: Stipes.

Hungerford, H. R., \& Volk, T. L. (1990). Changing learner behavior through environmental education. The Journal of Environmental Education, 21(3), 8-21.

Hsu, S. J., \& Roth, R. E. (1999). Predicting Taiwanese secondary teachers' responsible environmental behavior through environmental literacy variables. The Journal of Environmental Education, 30(4), 11-18.

Hungerford, H. R., Peyton, B. R.,\& Wilke, R. J. (1980). Goals for curriculum development in environmental education. The Journal of Environmental Education, 11(3), $42-47$.

Ignat, A. A., \& Clipa, O. (2010). The impact of self-efficacy and locus of control on the professional development of the teachers. Buletinul Universitatii Petrol-Gaze din Ploiesti [Petroleum-Gas University of Ploiesti Bulletin], 12(1), 180-185.

Kolb, D. (1984). Experiential learning. Experience as the source of learning and development. Upper Saddle River, New Jersey: Prentice Hall, Inc.

Marcinkowski, T. (2004). Using a logic model to review and analyze an environmental education program. Washington: North American Association for Environmental Education.

Matejcek, T.,\& Bartos, J. (2012). Environmentalni gramotnost ucitelu a studentu ucitelstvi. [Environmental literacy of pre-service and in-service teachers]. Envigogika, 7(2). Retrieved October 10, 2013, fromhttp://envigogika.cuni.cz/index.php/Envigogika/ issue/view/21

MSMT (Ministerstvo skolstvi, mladeze a telovychovy [the Ministry of Education]). (2008). Metodicky pokyn MSMT $k$ zajisteni environmentalniho vzdelavani, vychovy a osvety (EVVO)[Guidelines of the Ministry of Education for providing environmental education]. Retrieved October 10, 2013, from http:// www.msmt.cz/uploads/ soubory/zakladni/VN_MP_EVVO_2008.pdf 
Morgan, D. L. (1997). Focus groups as qualitative research. Thousand Oaks: Sage.

Moseley, C., Reinke, K., \& Bookout, V. (2002). The effect of teaching in an outdoor environmental education program on elementary pre-service teachers' environmental education self-efficacy and outcome expectancy. The Journal of Environmental Education, 34(1), 9-15.

NAAEE (North American Association for Environmental Education). (2010). Guidelines for the preparation and professional development of environmental educators. Washington: North American Association for Environmental Education.

NAAEE (North American Association for Environmental Education). (2004). Nonformal environmental education programs - guidelines for excellence. Washington: North American Association for Environmental Education.

Pace, P. (2010). Self-evaluation as a tool in developing environmental responsibility. Journal of Teacher Education for Sustainability, 12(1), 5-26.

Parpala, A., Lindblom-Yläne, S., \& Rytkönen, H. (2011) Students' conceptions of good teaching in three disciplines. Assessment \& Evaluation in Higher Education, 36(5), $549-563$.

Patton, M. Q. (2002). Qualitative research and evaluation methods. Thousand Oaks: Sage.

Pe'er, S., Goldman, D., \& Yavetz, B. (2007). Environmental literacy in teacher training: attitudes, knowledge, and environmental behavior of beginning students. The Journal o fEnvironmental Education, 39(1), 45-59.

Postareff, L. (2007). Teaching in higher education. From content-focused to learningfocused approaches to training. Helsinki: University of Helsinki.

Rich, P., \& Hannafin, M. (2009). Scaffolded video self-analysis: Discrepancies between preservice teachers perceived and actual instructional decisions. The Journal of Computing in Higher Education, 21, 128-145.

Saldana, J. (2009). The coding manual for qualitative research. Los Angeles: Sage.

Santiago, P., Gilmore, A., Nusche, D., \& Sammons, P. (2012). OECD reviews of evaluation and assessment in education: Czech Republic 2012, OECD Publishing. Retrieved October 10, 2013, fromhttp://dx.doi.org/10.1787/9789264116788-en

Stevenson, R. B. (2007). Schooling and environmental education: Contradictions in purpose and practice. Environmental Education Research, 13(2), 139-153.

Winther, A. A. (2005). Research related to staff development in environmental education. In B. Simmons (Ed.), Preparing effective environmental educators (pp. 59-72). Washington: North American Association for Environmental Education.

Winther, A. A., Volk, T. L., \& Schrock, S. A. (2002). Teacher decision making in the $1^{\text {st }}$ year of implementing an issues-based environmental education program: A qualitative study. The Journal of Environmental Education, 33(3), 27-33.

\section{Correspondence:}

Jan Cincera, PhD, the Technical university of Liberec, Faculty of Science, Humanities and Education, Department of Education and Psychology. 1. maje 870/14 Liberec 3 460 03, the Czech Republic. Tel.: +420 48535 4445. Email: jan.cincera@tul.cz 